\title{
Biological ammonia removal from drinking water in fluidized bed reactors
}

\author{
M. Aboabboud, H. Ibrahim \& A. Awad \\ Chemical Engineering Department, Faculty of Engineering, \\ Al-Mergheb University, Al-Khoms, Libya
}

\begin{abstract}
Ground water is the most reliable source of drinking water and frequently contains ammonia as a pollutant in concentrations up to $3 \mathrm{mg} / \mathrm{L}$. The recommended maximum concentration level (MCL) according to the World Health Organization (WHO) is $0.5 \mathrm{mg} / \mathrm{L}$. Concentrations in excess of this in drinking water can be oxidized to toxic nitrite, support the growth of bacteria, (Nitrosomonas and Nitrobacter), and create taste and other problems in treatment plants and the distribution network. High ammonia concentrations also create high chlorine demand during disinfection that consequently produces trihalomethanes and organochlorines suspected to be carcinogenic. In this work the biological oxidation of ammonia to nitrite and consequently to nitrate by nitrifying bacteria, Nitrosomonas and Nitrobacter was studied in two fluidized bed reactors, each having one type of biofilm supporting material: sand and granular activated carbon (GAC). The aim was mainly to investigate the possibility of ammonia oxidation to nitrate when the ammonia concentration is low, and how the support materials influence the starting up period and the rate of ammonia oxidation capacity of the nitrification process. In this study the main equipment used were two reactors and an aerator, which were made of Plexiglas tubes. Synthetic water containing ammonia nitrogen $(1-3 \mathrm{mg} / \mathrm{L})$ was fed to the reactors in fluidization mode. Both GAC and sand reactors gave ammonianitrogen $\left(\mathrm{NH}_{4}{ }^{+}-\mathrm{N}\right)$ oxidation capacity up to $2.5 \mathrm{~kg} / \mathrm{m}^{3}$ of nitrogen per day. The type of the support material that was found to be successful in nitrification is GAC. Nitrification in the sand reactor proceeded at a very slow rate compared to the GAC reactor. The GAC reactor had a higher oxidation rate and steeper curve compared to the sand reactor and reached maximum nitrite production earlier than the sand reactor.
\end{abstract}

Keywords: biological treatment, fluidization, biofilm, GAC, nitrosomonas, nitrobacter. 


\section{Introduction}

Ground water is the most reliable source of drinking water and frequently contains methane, ammonia, ferrous iron and manganese. The most usual concentration ranges for these pollutants are as follows: 2 to $8 \mathrm{mg} / \mathrm{L}, 1$ to 3 $\mathrm{mg} / \mathrm{L}, 0.5$ to $10 \mathrm{mg} / \mathrm{L}$ and 0.5 to $1.5 \mathrm{mg} / \mathrm{L}$ respectively. The recommended maximum concentration level (MCL) for methane is $0.8 \mathrm{mg} / \mathrm{L}$ [1]. Methane concentrations above this may result in explosions in water storing facilities.

The MCL of $\mathrm{NH}_{3}-\mathrm{N}$ is $0.5 \mathrm{mg} / \mathrm{L}$ [2], concentrations in excess of this can support the growth of ammonia-oxidizing micro-organisms in treatment plants and distribution systems producing organic compounds as a cell material, which in turn support the growth of heterotrophic bacteria that are sometimes pathogenic and create taste and odour problems. Due to the ammonia chlorine demand [3], one mole of ammonia requires 1.5 moles of chlorine; this on a weight basis is 7.5 parts of chlorine to 1 part of $\mathrm{NH}_{3}-\mathrm{N}$. For this reason ammonia exerts a high chlorine demand that must be satisfied before chlorine is available for disinfection and some residual remains in the water. High chlorine dosages may produce trihalomethanes and add chlorine ions to the system [4].

Chemical processes conventionally combined with filtration are used to remove these pollutants, but theses methods are sometimes costly and ineffective. Biological oxidation of ammonia gives another alternative for removing these pollutants by biofilm processes when the concentration of pollutants is low, as in the case of drinking water. The attachment of bacteria to a support material in a bioreactor allows a large quantity of biomass accumulation.

The reactors used are either of fixed bed or fluidized bed type. Fluidized bed bioreactors are favourable for drinking water treatment since they prevent clogging and eliminate the need for back washing. Support materials used in these types of reactors have a high specific surface area that provides high biomass density and hence high pollutant removal. The principle drawback of nitrifying fluidized bed reactors is the difficulty of supplying oxygen.

\section{Theory}

\subsection{Nitrification}

Nitrification and nitratification are defined as the biological oxidative conversion of ammonia to nitrite and nitrite to nitrate, respectively by nitrifying microorganisms in the presence of molecular oxygen. They produce energy from reactions to be used for growth and maintenance.

The oxidation of ammonia to nitrite and nitrite to nitrate in the presence of micro-organisms and dissolved oxygen is given by [5] the following reaction:

$$
\begin{gathered}
\mathrm{NH}_{4}^{+}+1.5 \mathrm{O}_{2} \rightarrow \mathrm{NO}_{2}^{-}+2 \mathrm{H}^{+}+\mathrm{H}_{2} \mathrm{O}+58-84 \mathrm{kcal} / \mathrm{mole} \\
\mathrm{NO}_{2}^{-}+0.5 \mathrm{O}_{2} \rightarrow \mathrm{NO}_{3}^{-}+15.4-20.9 \mathrm{kcal} / \mathrm{mole}
\end{gathered}
$$

Eqns. (1) and (2) serve as the energy yielding reactions for the micro-organism responsible for the reaction. 
Based on the representative yield measurement and oxygen consumption in the activated sludge, waste water treatment is represented by the formula $[5,6]$ $\mathrm{C}_{5} \mathrm{H}_{7} \mathrm{O}_{2} \mathrm{~N}$ for the biomass. The energy produced by eqn. (1) is utilized partly to give new biomass as represented by eqn. (3):

$$
\begin{gathered}
75 \mathrm{CO}_{2}+65 \mathrm{NH}_{3} \longrightarrow 50 \mathrm{NO}_{2}^{-}+115 \mathrm{H}^{+}+15 \mathrm{C}_{5} \mathrm{H}_{7} \mathrm{O}_{2} \mathrm{~N}+20 \mathrm{H}_{2} \mathrm{O} \\
\text { new biomass }
\end{gathered}
$$

The combination of eqns (1) and (3) gives the overall nitrification process and is represented by eqn. (4):

$$
55 \mathrm{NH}_{4}^{+}+50 \mathrm{CO}_{2}+76 \mathrm{O}_{2} \longrightarrow \mathrm{C}_{5} \mathrm{H}_{7} \mathrm{O}_{2} \mathrm{~N}+54 \mathrm{NO}_{2}^{-}+52 \mathrm{H}_{2} \mathrm{O}+109 \mathrm{H}^{+}
$$

This indicates that only $1.8 \%$ of the original nitrogen oxidized is used for synthesis. The yield based on eqn. (4) for the oxidation of $\mathrm{NH}_{4}{ }^{+}-\mathrm{N}$ to $\mathrm{NO}_{2}^{-}$is 0.146 . The yield reported [5] for the oxidation of $\mathrm{NH}_{4}^{+}-\mathrm{N}$ by Nitrosomonas bacteria based on experimental mixed culture is between 0.04 and 0.3 and that based on pure culture is 0.29 . Other reported [7-9] values for the Nitrosomonas yield are between 0.06 and 0.13 .

The growth or synthesis of new biomass of nitrite oxidizers with the energy supply from eqn. (2) is given by eqn. (5):

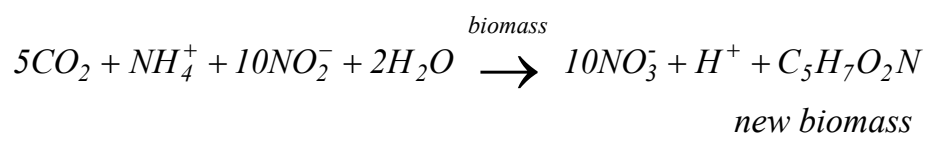

The overall oxidation process of nitrite is given by a combination of eqns. (2) and (5) and represented by eqn. (6):

$$
5 \mathrm{CO}_{2}+\mathrm{NH}_{4}^{+}+2 \mathrm{H}_{2} \mathrm{O}+195 \mathrm{O}_{2}+400 \mathrm{NO}_{2}^{-} \rightarrow \mathrm{C}_{5} \mathrm{H}_{7} \mathrm{O}_{2} \mathrm{~N}+400 \mathrm{NO}_{3}^{-}+\mathrm{H}^{+}
$$

The yield of biomass based on eqn. (6) is 0.02. Yields reported [5] for Nitrobacter based on experimental mixed culture are between 0.02 and 0.07 and that based on pure culture is 0.084 . Other values for Nitrobacter yields were reported $[10,11]$ as 0.02 for batch culture and for continuous culture [3] between a 0.04 and 0.07 . Beccari et al. [12] obtained a yield value of 0.07 for Nitrobacter.

\subsection{Microbiology}

Many different micro-organisms are capable of producing nitrite and nitrate from organic and inorganic compounds. This is accomplished through a mechanism that may not be oxidative and is not the sole energy source of the microorganism. This indicates that nitrification can be accomplished both heterotrophically and autotrophically [13].

The first stage of nitrification is conversion of ammonia to nitrite, which is accomplished by the oxidation of ammonia in the presence of oxygen and Nitrosomonas bacteria [14]. The second stage of nitrification is the oxidative conversion of nitrite to nitrate in the presence of oxygen, which is accomplished by Nitrobacter bacteria [15]. 


\section{Experimental work}

The experimental setup for biological nitrification of drinking water is shown in fig. 1. It consists of an aerator, sand reactor, granular activated carbon (GAC) reactor, heater and feed stock tank containing ammonia bicarbonate solution.

In the experiment, tap water was fed to the aerator (stock feed column) through two lines; one passes directly to the aerator and the other through a heater. The total water flow was 107 and $69 \mathrm{~L} / \mathrm{hr}$ for sand and GAC reactors respectively. Air was supplied at the bottom of the aerator column through a distributor at a rate of $120 \mathrm{~L} / \mathrm{hr}$ in counter-current mode. The water residence time in the aerator was between 2.67 and 4.62 minutes during the experimental period. The aerator column was also used as the stock raw water feed to the reactors by gravity. The water level in the aerator at the overflow point was higher than the reactor outlet points by $155 \mathrm{~cm}$, which was the driving force for the flow.

The substrate ammonia solution concentration was $926 \mathrm{mg} \mathrm{NH}{ }_{4}^{+}-\mathrm{N} / \mathrm{L}$. This solution was fed to the aerator column via a peristaltic pump at a rate of 0.45 $\mathrm{L} / \mathrm{hr}$ at a point near the bottom of the aerator to allow good mixing with the

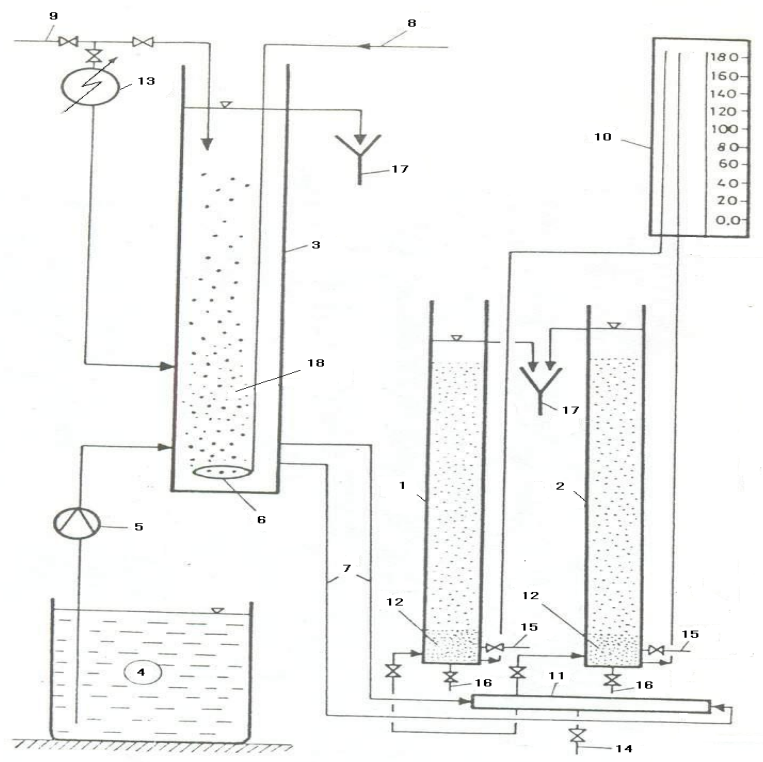

1. Sand reactor (1-1.25 mm)

4. Substrate tank.

7. Ineffluent to the reactor

10. Manometer.

13. Hearer.

16. Drainage.
2. Activated Carbon reactor $(0.7-2.5 \mathrm{~mm})$. 3. Stock feeding and aeration column.

5. Substrate pump.

8. Air supply.

11. Water distributor.

14. Sampling point.

17. To Canalization.
6. Air distributor.

9. Ambient water supply.

12. Gravel.

15. Air scoring.

18. Air bubbles.

Figure 1: $\quad$ Set-up for ammonia removal from drinking water in fluidized bed reactors. 
oxygen saturated water, creating synthetic water (raw water polluted with ammonia). When a different feed temperature to the reactors was needed, a portion of tap water was passed through a heating vessel and consequently was fed by gravity at a point above the aerator bottom to allow mixing with ambient tap water.

The feed water to the reactors was saturated with oxygen and its ammonianitrogen concentration was between 0.705 and $3 \mathrm{mg}-\mathrm{N} / \mathrm{L}$ during the experimental period. This water was distributed by a distributor to the two reactors. Samples for analysis were taken from a sampling point at the distributor. The water flow rate to each reactor was adjusted by a valve at the inlet of each reactor in order to allow working at the fluidization velocity of the bed. Higher flow rates were required in order to fluidize the whole bed due to the wide difference in particle size. This resulted in vigorous fluidization of the upper part of the beds. The complete fluidization velocity for the sand bed was about $55 \mathrm{~m} / \mathrm{hr}$ and for the GAC was about $35 \mathrm{~m} / \mathrm{hr}$.

\section{Measurement and analytical methods}

Samples from the inlet and outlet stream of the reactors were collected daily for analysis of $\mathrm{NH}_{4}{ }^{+}-\mathrm{N}$ and $\mathrm{NO}_{2}{ }^{-} \mathrm{N} ; \mathrm{NO}_{3}{ }^{-} \mathrm{N}$, oxygen and $\mathrm{pH}$ were measured sometimes. Immediately before collecting the samples the temperature was measured with a mercury thermometer and the flow rate to each reactor was measured volumetrically.

The fluidization velocity for each reactor loaded with the corresponding clean biofilm supporting material listed earlier was measured for each reactor by increasing the water flow rate through the bed stepwise until head loss did not change and stayed constant and any change in the flow resulted only in bed expansion.

The superficial velocity is calculated by:

$$
v=\frac{Q}{A}
$$

where $v$ is the superficial velocity, $(\mathrm{m} / \mathrm{hr}) ; Q$ is the volumetric flow rate $\left(\mathrm{m}^{3} / \mathrm{hr}\right)$ and $A$ is the cross sectional area of empty reactor.

Analysis of $\mathrm{NH}_{4}^{+}-\mathrm{N}$, nitrite- $\mathrm{N}$ and nitrate- $\mathrm{N}$ was determined according to the standard methods [17].

\section{Calculations}

The rate of ammonia oxidation was calculated using the following equation:

$$
\text { rate } \text { (capacity) }=\frac{Q}{V}\left(S_{1}-S_{o}\right)
$$

where $Q$ is the flow to the reactor, $\left(\mathrm{m}^{3} /\right.$ day); $S_{l}$ and $S_{o}$ are the inlet and outlet $\mathrm{NH}_{4}{ }^{+}-\mathrm{N}$ respectively; and $V$ is the volume of freely settled support medium $\left(\mathrm{m}^{3}\right)$.

The load on the reactor was calculated by eqn. (9):

$$
\text { Load }=Q^{*} S
$$

where load is in $\left(\mathrm{kg}-\mathrm{N} / \mathrm{m}^{3}\right.$.day) and $S$ is an influent $\mathrm{NH}_{4}{ }^{+}-\mathrm{N} ;\left(\mathrm{kg}-\mathrm{N} / \mathrm{m}^{3}\right)$. 
The nitrification ratio was calculated by eqn. (10):

$$
\text { Nitrification ratio }=\frac{\left(\mathrm{NO}_{2}^{-}-\mathrm{N}\right)}{\left(\mathrm{NO}_{2}^{-}-\mathrm{N}\right)+\left(\mathrm{NO}_{3}^{-}-\mathrm{N}\right)} * 100
$$

\section{Operation of the reactors}

\subsection{Origin of the support material}

\subsubsection{Sand}

The sand was brought from a waste water nitrification plant and so had little removal capacity

\subsubsection{Activated carbon}

The activated carbon was fresh and had no adsorption capacity to ammonia nitrite and nitrate.

\subsection{Seeding}

In the first few days of operation the reactors were operated at lower velocity than that required for fluidization in order to allow biomass attachment to the support material and minimize forces on the particles.

After 12 days of operation the sand reactor showed no improvement in the removal capacity and the other reactor did not show any ammonia oxidation at all. The lack of improvement in the removal capacity had made inoculation of the reactors a must in order to accelerate the start up of the process.

The inoculation of the reactors was executed in the following manner.

\subsubsection{Polyelectrolyte treatment}

The support material in each of the two reactors was treated by polyelectrolyte (Prestol 434) in order to create a higher adsorption capacity for biomass on the surface of the material. One litre of concentration $1 \mathrm{~g} / \mathrm{L}$ of polyelectrolyte was mixed with the feed water to the reactors.

\subsubsection{Bacteria seeding}

The reactors were seeded by a nitrifying sludge that was taken from an activated sludge reactor. One litre of this sludge was mixed with the raw water and fed into the reactors. The previous two steps were repeated for two consecutive days.

\section{Results and discussion}

The results of biological nitrification in the sand and GAC reactors are shown in figures 2 and 3. The capacity was calculated by eqn. (8), the load by eqn. (9) and the nitrification ratio by eqn. (10).

The starting up period of the reactors was characterized by four periods.

In the first period, the reactors were started at the ambient water temperature of $10.5^{\circ} \mathrm{C}$ for about eighteen days of continuous operation. Both sand and GAC 
reactors had shown no improvement in the $\mathrm{NH}_{4}{ }^{+}-\mathrm{N}$ oxidation capacity. During this period, the nitrifiers' attachment and detachment are the same and even though the growth was noticed there was no improvement in the $\mathrm{NH}_{4}{ }^{+} \mathrm{N}$ oxidation capacity.

In the second period, 24 days after the starting day of the reactors operation, both the sand and GAC reactors responded with more $\mathrm{NH}_{4}{ }^{+}-\mathrm{N}$ oxidation capacity as shown in fig. 2. More bacterial growth and attachment were taking place. The attachment and growth of nitrifies were stronger than the detachment, these resulted in more bacterial accumulation on the surface of the support material. As shown in fig. 2, the GAC reactor reached the maximum oxidation capacity of about $\left(2.3 \mathrm{~kg}-\mathrm{N} / \mathrm{m}^{3}\right.$.day) at $20{ }^{\circ} \mathrm{C}$ in 50 days. The capacity of GAC was limited by the $\mathrm{O}_{2}$ supply and $\mathrm{NH}_{4}{ }^{+}-\mathrm{N}$ load applied since higher flow rates cannot be applied due to high bed expansion. The sand reactor took about 68 days to reach maximum $\mathrm{NH}_{4}{ }^{+}-\mathrm{N}$ oxidation.

Oxygen was not a limiting substrate in the sand reactor because of the high flow rate to the sand reactor and slow growth and attachment on the sand surface. The difference between the GAC and the sand reactors $\mathrm{NH}_{4}{ }^{+}-\mathrm{N}$ oxidation capacity as in fig. 2 was probably due to the difference in the surface nature between the two biofilm support materials. The rough non-uniform surface and high pore concentration in GAC (high surface area) had made bacteria attachment stronger than detachment. This resulted in a steeper change in the $\mathrm{NH}_{4}{ }^{+}-\mathrm{N}$ oxidation rate. Sand particles are more uniform and smooth than GAC particles and have no pores (less surface area than GAC). This resulted in a lower rate of attachment of nitrifiers to the sand surface. The GAC reactor had reached the highest possible $\mathrm{NH}_{4}{ }^{+}-\mathrm{N}$ oxidation capacity according to the experiment limitation (oxygen supply and $\mathrm{NH}_{4}{ }^{+}-\mathrm{N}$ load applied) eighteen days earlier than the sand reactor did.

This period can be seen in figs. 3 and 5 for both sand and GAC reactors for comparison. Negligible $\mathrm{NO}_{3}{ }^{-}-\mathrm{N}$ production was detected in this period for both reactors. This is due to the slow growth of Nitrobacter. This period was a

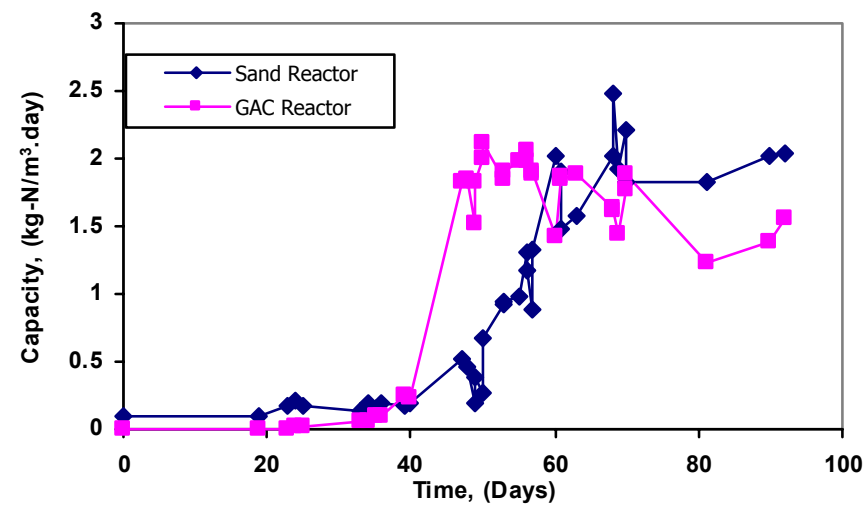

Figure 2: $\quad$ Comparison of capacity for the sand and GAC reactors. 
characteristic of Nitrosomonas attachment and growth. $\mathrm{NH}_{4}^{+}-\mathrm{N}$ oxidizers have a higher observed yield (0.04-0.13) than $\mathrm{NO}_{2}^{-}-\mathrm{N}$ oxidizers; Nitrobacter $(0.02-0.7)$ as can be seen from the negligible $\mathrm{NO}_{3}{ }^{-} \mathrm{N}$ production in fig. 4 . It took 50 days to reach this high $\mathrm{NO}_{2}^{-}-\mathrm{N}$ production in the GAC reactor and 68 days in the sand reactor.

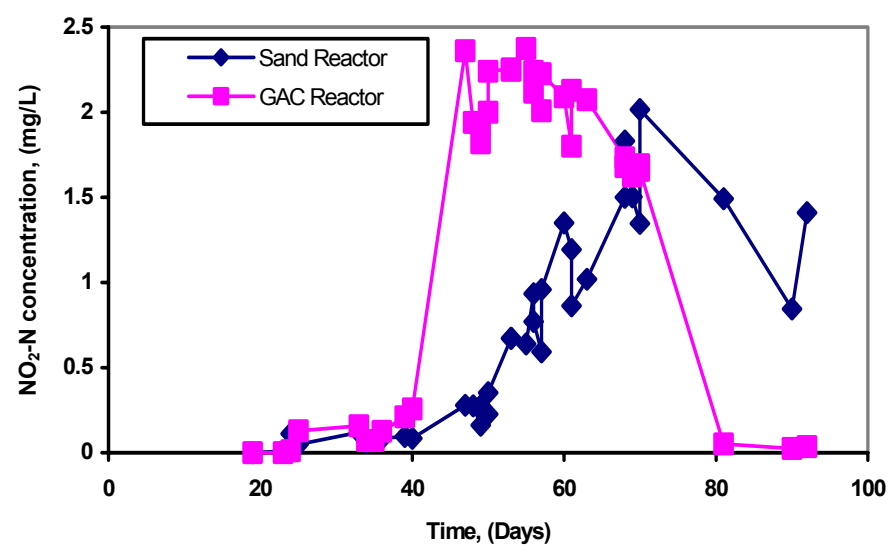

Figure 3: $\quad$ Comparison of $\mathrm{NO}_{2}^{-}-\mathrm{N}$ production for Sand and GAC reactors.

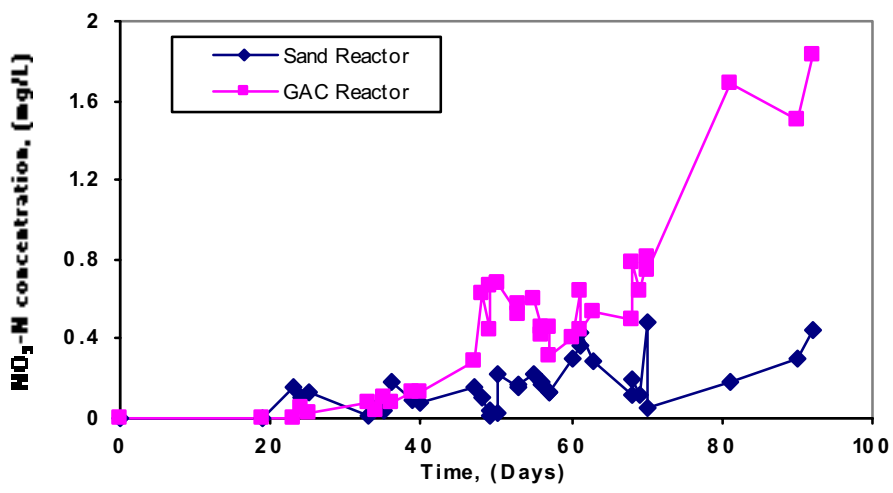

Figure 4: Comparison of $\mathrm{NO}_{3}^{-}-\mathrm{N}$ production for the sand and GAC reactors.

This low yield of Nitrobacter made longer periods of $\mathrm{NO}_{2}^{-}-\mathrm{N}$ production. $\mathrm{NO}_{2}{ }^{-} \mathrm{N}$ accumulation is undesirable in the case of drinking water treatment since $\mathrm{NO}_{2}{ }^{-}-\mathrm{N}$ is toxic $(1 \mathrm{mg} / \mathrm{L})$; complete $\mathrm{NO}_{2}{ }^{-} \mathrm{N}$ is the bottle-neck of the process.

The third period was characterized by stable $\mathrm{NO}_{2}^{-}-\mathrm{N}$ production as can be seen in figs. 3 and 5. For the GAC reactor this period was about twenty days, in which the Nitrosomonas were performing in a better state. The sand reactor reached the maximum nitrite production later than the GAC reactor (see fig. 3). During this period the very slow growing Nitrobacter attachment and growth are 
taking place. During this period from $\mathrm{NO}_{2}^{-}-\mathrm{N}$ and $\mathrm{NO}_{3}{ }^{-}-\mathrm{N}$ concentration measurements it was observed that Nitrobacter was very sensitive to the changes in the environmental conditions. This can be seen from the fluctuation in $\mathrm{NO}_{3}{ }^{-} \mathrm{N}$ production in fig. 4 due to temperature changes. This long period of $\mathrm{NO}_{2}{ }^{-} \mathrm{N}$ production was an indication of the relatively fast attachment and growth of Nitrosomonas, with comparison to Nitrobacter that had low yield and weaker attachment.

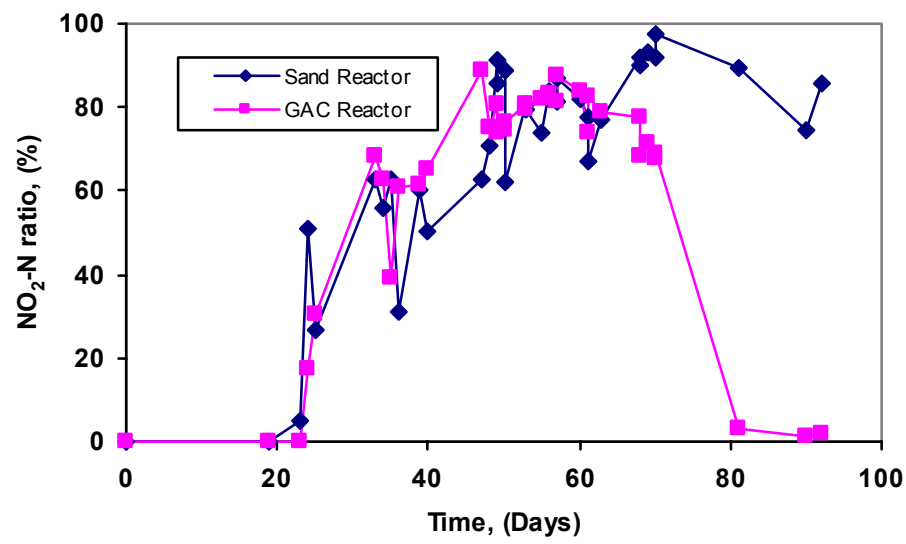

Figure 5: $\quad$ Comparison of $\mathrm{NO}_{2}^{-}-\mathrm{N}$ ratio for the sand and GAC reactors.

The fourth period was characterized by $\mathrm{NO}_{3}{ }^{-} \mathrm{N}$ production. In this period Nitrobacter attachment and growth was more pronounceable. In the case of the GAC reactor more $\mathrm{NO}_{3}{ }^{-}-\mathrm{N}$ production was achieved as in fig. 4. This period was characteristic of Nitrobacter attachment and growth. Full $\mathrm{NO}_{2}^{-}-\mathrm{N}$ oxidation to $\mathrm{NO}_{3}{ }^{-}-\mathrm{N}$ was complete on day 81 as shown in fig. 3. The $\mathrm{NO}_{2}{ }^{-}-\mathrm{N}$ ratio shown in fig. 5 for both was very high for the sand reactor through the time course of the experiment. Full nitratification in the sand reactor was not achieved in the limited experimental period of 92 days. Probably more time is required for Nitrobacter attachment and growth. Tanaka and Dunn [16] reported that Nitrobacter needed 2 to 3 months to be acclimated.

The nitratification process for $\mathrm{NO}_{2}^{-}-\mathrm{N}$ oxidation is the bottle-neck of the process of nitrification. In terms of $\mathrm{NH}_{4}{ }^{+}-\mathrm{N}$ oxidation as shown in fig. 2 for the sand reactor, $\mathrm{NH}_{4}{ }^{+}-\mathrm{N}$ oxidation capacities of $2.5 \mathrm{~kg}-\mathrm{N} /\left(\mathrm{m}^{3}\right.$.day) were possible to $\mathrm{NO}_{2}{ }^{-}-\mathrm{N}$. This is about $90 \%$ of $\mathrm{NH}_{4}{ }^{+}-\mathrm{N}$ go to $\mathrm{NO}_{2}^{-}-\mathrm{N}$. There were no limiting substrates. In the case of GAC the $\mathrm{NH}_{4}{ }^{+}-\mathrm{N}$ oxidation capacity had reached to 2.3 $\mathrm{kg}-\mathrm{N} / \mathrm{m}^{3}$.day during the nitrite accumulation period. The capacity was limited by oxygen supply. When Nitrobacter growth and attachment was achieved less ammonia was oxidized due to the Nitrobacter need for oxygen and the load to the reactor was decreased in order to keep at last $0.2 \mathrm{mg} / \mathrm{L}$ of oxygen in the effluent. 


\section{Conclusion}

Both support materials used in the experiment were successful in nitrification of low ammonia concentrations in drinking water. Both reactors were capable of ammonia oxidation to nitrite up to a value of $2.5 \mathrm{~kg}-\mathrm{N} / \mathrm{m}^{3}$.day. GAC reached maximum possible $\mathrm{NH}_{4}{ }^{+}-\mathrm{N}$ oxidation to $\mathrm{NO}_{2}^{-}-\mathrm{N}$ about twenty days earlier than the sand did. It took about eighty days for the GAC reactor to achieve complete conversion of ammonia to nitrate with a capacity value as high as $2 \mathrm{~kg}-\mathrm{NH}_{4}{ }^{+}-$ $\mathrm{N} / \mathrm{m}^{3}$.day. GAC capacity was limited by oxygen supply and the load (due to high bed expansion that limits the applied flow). This period was not enough for the sand reactor to achieve complete conversion to nitrate.

Higher ammonia oxidation capacities up to $6 \mathrm{~kg}-\mathrm{N} / \mathrm{m}^{3}$.day are possible in the GAC reactor provided enough oxygen supply, but this capacity cannot be achieved on an industrial scale due to the wide size of particle distribution and the high bed expansion when operating at high flow rate. The sand reactor had neither substrate nor oxygen limitations.

In the GAC reactor complete ammonia conversion to nitrate was found to be very stable operating at different loads (the load did not exceed the Nitrobacter capacity), for instance increasing the load to the reactor had little effect on the rate of nitrification. This is due to the ability of the fluidized bed to accumulate a large biofilm more than that required to effect complete $\mathrm{NH}_{4}{ }^{+}-\mathrm{N}$ conversion and hence sufficient quantities of nitrifying bacteria remain to achieve complete nitrification provided there is enough oxygen supply.

In spite of the high capacity and complete nitrification that are attainable by the GAC reactor, some difficulties arise when using GAC in industrial scale water treatment plants, such as its low mechanical strength when regeneration is required and its high price compared to sand. This makes sand more attractive if better ways and operating conditions are sought to concentrate Nitrobacter on the sand surface.

\section{References}

[1] Hungarian standard MSz 450-1/89.

[2] Academy of engineering water quality criterion. Report by common quality criteria at request of US EPA Washington D.C., 1972.

[3] Gauntlett, R. B., Removal of ammonia and nitrate in the treatment of potable water (Chapter 3). In Biological Fluidized Bed Treatment of Water and Wastewater, Ellis Horwood Chichester, pp. 48-60, 1981.

[4] Matson, J. V., Andrews, J. F. and Garrett, M. T., Reduction in chlorine requirements by control of nitrification in an activated sludge plants with "Mannoth" rotor aerator. Prog. Water Techn., 8(4/5), pp. 625-637, 1982.

[5] Environmental Protection Agency, Process design manual for nitrogen control. Office of Technology Transfer Cincinnati Ohio, 1975.

[6] Water Research Centre, Stevenage. Nitrifcation in BOD test, votes on water pollution, No. 52, 1971. 
[7] Nelson, D. H., Isolation and characterization of Nitrosomonas and Nitrobacter, Zentbl. Bakt. Parasit. K. Abt., 1183, pp. 280-311, 1931.

[8] Skinner, F. A. and Walker, N., Growth of Nitrosomonas europaea in batch and continuous culture, Acta. Microbiol., 38, pp. 339-349, 1961.

[9] Bass-Becking, L. A. M. and Park, G.S., Energy relation in metabolism of autotrophic bacteria, Physical Rev., 7, pp. 85-106, 1927.

[10] Lees, H. and Simpson, J. R., The biochemistry of nitrifying organisms, part 5. Nitrite oxidation by Nitrobacter, Biochem. J., 85, pp. 440-447, 1975.

[11] Boon, B. and Landelout, H., Kinetic of nitrite oxidation by Nitrobacter Winogradski, Biochem. J., 85, pp. 440-447, 1962.

[12] Beccari, M., Marani, D. and Ramadori, R., A critical analysis of nitrification alternative, Water Res., 13, pp. 185-192, 1979.

[13] Painter, H. A., Microbial transformation of inorganic nitrogen, Prog. Water Technology, 8(4/5), pp. 1983, 1977.

[14] Bremner, J. M. and Blackner, A. M., Terrestrial nitrification as a source of atmospheric nitrous oxide (Chapter 8). In Denit. Nitr. and atmospheric nitrous oxide, ed. Delwiche, Wiley, pp. 151-170, 1981.

[15] Zavarin, G. and Iegunkova, R., The morphology of Nitrbacter, J. gen. Micr-obiol., 21, pp. 186-190, 1959.

[16] Tanaka, H. and Dunn, I. J., Kinetic of biofilm nitrification, Biotechnol. Bioeng., 24, pp. 669-689, 1982.

[17] Standard methods for the examination of water and wastewater, $15^{\text {th }}$ edition, APHA-AWWA-WPCF, 1980. 